\title{
A Novel 'Stakeholder Sustainability Knowledge Management' (SSKM) Model: Developing Linkages of Stakeholder Management, Knowledge Management and Triple Bottom Line Performance
}

\author{
Egbunike, F.C.
}

Department of Accountancy, Faculty of Management Sciences

Nnamdi Azikiwe University, P.M.B.5025, Awka Nigeria

chineduegbunike@ rocketmail.com DL:+2348132850409

\section{Echekoba, F.N.}

Department of Banking \& Finance, Faculty of Management Sciences

Nnamdi Azikiwe University, P.m.b.5025, Awka Nigeria

nwaolisa@yahoo.com; echekoba@gmail.com DL:+2348036146005

\section{Udeh, F.N.}

Department of Accountancy, Faculty of Management Sciences

Nnamdi Azikiwe University, P.M.B.5025, Awka Nigeria

\section{Abstract}

This paper proposes a novel 'Stakeholder Sustainability Knowledge Management' (SSKM) model for corporate managers by integrating three performance dimensions (Stakeholder management, knowledge management and triple bottom line). These concepts have separately been discussed in management literatures as critical success factors for sustainable performance of organizations. As corporate stakeholders absorb knowledge (economic knowledge, social knowledge and environmental knowledge) to judge corporate behaviour, it is proposed that a knowledge management system for re-absorption and utilization of such knowledge by organizations would ultimately strengthen triple bottom line performance of the corporation. Using a sample of 56 respondents, comprising 21 corporate managers and 25 academics, this study examined the connection between stakeholder management, knowledge management and sustainable performance. Three hypotheses were formulated and tested in the study. In addition to descriptive statistics, Two-Sample Kolmogorov-Smirnov test was used in analyzing the primary data. The results of empirical data analysis proved that knowledge is considered as a veritable and succinct organizational resource. And a system for assessing stakeholder needs based on the knowledge absorption process would ultimately meet triple bottom line performance of sustainable organizations. Based on this a framework for the absorption and utilization of such knowledge was proposed. 
Keywords: Knowledge Management, Triple Bottom Line, Stakeholder management.

\section{Introduction}

The view that organizations are not only created to serve the needs of shareholders to the detriment of other corporate stakeholders (Freeman 1984; Reich, 1998; Post et-al., 2002; Brown and Fraser, 2006; Steurer, 2006), the sustainability discuss (World Business Council for Sustainable Development, 1987) leading to emergence of the triple bottom line catchphrase (Elkinton, 1994) and rise of the knowledge economy (Gloet, 2006) presented modern corporations with new issues underlying corporate performance measurement. Hubbard (2006) noted that measuring corporate performance is likely to become more complex in the future as stakeholder expectations about companies' economic, social and environmental responsibilities change Corporate performance for $21^{\text {st }}$ century organizations therefore requires the identification, measurement and inclusion of new performance metrics, reflecting a more diverse approach against the previous stakeholder economic basis of assessment (Hubbard, 2006). This calls for modification of existing corporate management models to incorporate more diverse goals that firms are currently faced with (Herciu et-al., 2011) so as to achieve long-term sustainable value for corporations (Osisioma, 2010).

Corporate sustainability that is the ability of a firm to carry out longterm operations depends on the sustainability of its stakeholder relations (Perrini \& Tencati, 2006) and meeting its triple bottom line dimensions (Fauzi et-al., 2011). Thus, corporate responsibility redefined refers $\mathrm{t}$ engaging in continuous stakeholder dialogues in order to address various stakeholder needs from a holistic perspective and where sustainable corporate conduct is managed with economic, environmental and social values in mind (Mark-Herbert et-al., 2010).

In a knowledge based society, knowledge management is a preeminent requirement for firms desiring competitive advantage (Herciu et-al., 2011) therefore, fostering sustainable development requires making knowledgeable interpretations and recommendations to support 
sustainability across a wide range of stakeholders (Gloet, 2006). Thus, to truly create and manage sustainable enterprises, managers of modern corporations require both stakeholder knowledge and sustainability knowledge for effective and efficient decision making. Thus, organizational and managerial practice has recently become more knowledge-focused (Alavi \& Leidner, 2001).

The primary objective of this paper is to identify the potential benefits of integrating stakeholder management, knowledge management and triple bottom line principles in the management of business operations by examining the areas of linkages between the three concepts (stakeholder management, knowledge management and triple bottom line performance). The lack of extant literatures exploring the nexus between the three paradigms prompted the study. The study is therefore set out to address the following.

1. To what extent would the synergistic effect derived from the interface of the three performance area, provide management with strategies for survival and growth in the long-run?

2. To what extent knowledge management systems lead to the development of Core Competencies in sustainable organizations by providing managers with knowledge capable of influencing environmental, social and economic reaction and adaptation of their firms?

3. To what extent corporate triple-bottom-line performance of organizations is strengthened by a sustainable stakeholder categorization for firms which provides managers with a system for assessing corporate stakeholder needs?

The paper is structured as follows: the first section reviews issues underlying corporate triple bottom line performance; the second, review corporate stakeholders and stakeholder management literatures, the third knowledge and organizational knowledge management perspectives. The fourth presents the synergy between the three paradigms. 


\section{Literature Review}

\section{Stakeholder Theory}

The diversity in stakeholder definition and classification stems from the varying contextual applications of the term in the literatures (Donaldson \& Preston, 1995; Jones \& Wicks, 1999). Freeman (1984) defined corporate stakeholders as 'any group or individual who can affect or is affected by, the achievement of a corporation's purpose'. Thus, stakeholders are broadly those persons and groups who contribute to the wealth-creating potential of the firm and are its potential beneficiaries (Mahoney, 2008) and/or those who voluntarily or involuntarily become exposed to risk from the activities of a firm (Clarkson, 1994; Mahoney, 2008; Sheng et-al., 2011). Corporate stakeholders are broadly divided into two: internal and external. Internal stakeholders are actors in the business organization. Examples include: employees, stakeholders, corporate proprietors and managers. External stakeholders are actors outside the business. Examples include: tax authorities, government, competitors, customers and the local community. The thrust of stakeholder theory is to assess organizational performance against the expectations of varying stakeholder groups that have unique identifiable interest in the operations and activities of the organization (Hubbard, 2006). The Balanced Scorecard (BSC) developed by Kaplan \& Norton (1992) utilizes stakeholder theory as its fundamental premise for corporate performance evaluation.

\section{Triple Bottom Line}

The term was coined by Elkington in 1994 in an attempt to create a new language to express what was perceived as an inevitable expansion of existing corporate models (Mark-Herbert et-al., 2010), from initial economic value orientation to a wider perspective encompassing social, and environmental values as an integral part of doing business (Hubbard, 2006). The author "expresses his conviction that businesses do not follow just one goal - to add (economic) value - but they have to follow other social and ecological responsibilities; by doing this, the accounting of tomorrow's operations will contain, together with the well known calculus of strictly economical efficiency, a balance sheet of the 
firm's activities effects on the environment and another one regarding the consequences of this activity over the social environment" (Herciu et-al., 2011). To create truly sustainable corporations a shift is necessary from the traditional financial bottom line to a wider perspective detailing the company's impact on to environment and society (Jackson, 2011). Elkington (2004) identified seven key drivers for organizations seeking sustainable development:

Table 1: Seven Key Drivers for Sustainable Organizations

\begin{tabular}{|l|l|l|l|}
\hline S/N & Drivers & Old paradigm & New paradigm \\
\hline 1. & Markets & Compliance & Competition \\
\hline 2. & Values & $\begin{array}{l}\text { Hard (economic } \\
\text { figures) }\end{array}$ & Soft (additional values) \\
\hline 3. & Communication & Closed (internal) & $\begin{array}{l}\text { Open (wider stakeholder } \\
\text { analysis) }\end{array}$ \\
\hline 4. & Partnerships & Subvention & Symbiosis (win win) \\
\hline 5. & $\begin{array}{l}\text { Life cycle } \\
\text { technology }\end{array}$ & $\begin{array}{l}\text { Focused on } \\
\text { Products }\end{array}$ & Focused on functions \\
\hline 6. & Time & Wide & Longer \\
\hline 7. & $\begin{array}{l}\text { Corporate } \\
\text { governance }\end{array}$ & Exclusive & Inclusive \\
\hline
\end{tabular}

Source: Mark-Herbert et-al., 2010

Various authors have identified benefits from implementing a triple bottom line strategy, to include: Enhanced marketplace (McEntyre, 2003) from an enhanced reputation and brand (Lewis, 2011); Securing a social license to operate (Lewis, 2011) from improved community services (McEntyre, 2003) and creation of a sound basis for stakeholder dialogue (Lewis, 2011); Attraction and retention of high caliber employees (Lewis, 2011); More efficient use of resources (McEntyre, 2003); Reduced risk profile and liabilities (McEntyre, 2003; Lewis, 2011); identification of potential cost savings (Lewis, 2011): Increased scope for innovation (Lewis, 2011).

Organizations showcase their commitment to the three complementary dimensions of sustainable development (economic, social and environmental) in the form of triple bottom line reports. Triple bottom 
line reports is a reporting approach aimed at expanding stakeholder knowledge of existing corporate activities (Jackson, 2011). Hubbard (2006) observed that triple bottom line is based on stakeholder theory, but with a wider perspective of the stakeholders affected by the organization than does the BSC approach. To fully account for their triple bottom line dimensions corporations need to incorporate additional information to better communicate with stakeholders on performance (Jackson, 2011).

\section{Knowledge Management (KM)}

The non-existence of a universally accepted definition of knowledge has resulted in the proliferation of views about the term. Authors identify and classify knowledge into various types (Gao etal., 2008; Hicks et-al., 2006; Wiig, 2004; Al Hawari \& Hassan, 2002; Choi \& Lee, 2002; Paisey, 2002; Nonaka et-al., 2000; Zack, 1999; Maiden \& Rugg, 1996; Nonaka \& Takeuchie, 1995; Polanyi, 1966), resulting in variants of knowledge management systems adopted in organizations (Shahbudin et-al., 2011; Kruger, 2010). Although information and data management are important ppillars of knowledge management (Shahbudin et-al., 2011), knowledge management encompasses broader issues - it embodies organizational processes that seek synergistic combination of data and information processing capacity of information technologies and the creative and innovative capacity of human beings (Kahreh, 2011).

$\mathrm{KM}$ is a system or a managerial approach to collecting, processing, and organizing enterprise-specific knowledge assets for business functions and decisions (Yao et-al., 2011). A critical task of KM is not to manage all knowledge resources, but those critical to organizational development (Mahdi et-al., 2011). Thus, the objective of organizational knowledge management system (KMS) is to support the creation, transfer and application of knowledge in organizations (Alavi \& Leidner, 2001). KM systems are context specific (Kahreh, 2011) and time biased, as frameworks adopted in one organization may be unsuitable for others (Karimzadegan et-al., 2011). 
The increasing turbulence and dynamism of modern business environment require that organizations not only process knowledge efficiently but also devise means of creating and managing it (Herciu et-al., 20101), thus, providing corporate managers with strategies to tackle issues related to organizational adaptation, survival and competence (kahreh, 2011). Organizations mostly adopt and implement knowledge management systems with the assumption that the result will be an increase in organizational effectiveness, efficiency, competitive advantage, value creation (Jivan and Zarandi, 2012; Mahdi et-al., 2011; Kahreh, 2011; Karimzadegan et-al., 2011; Momeni et-al., Shahbudin et-al., 2011; Massa and Testa, 2009; Gloet, 2006; King and Zeithalm, 2003; Nonaka and Takeuchi, 1995; Wiig, 1994) and as an indispensable ingredient for the development of dynamic core competencies (Kahreh, 2011; Herciu et-al., 2011) and, more generally, as a determinant factor for firms with global ambitions (kahreh 2011; Chang \& Wang, 2009). Herciu et-al., (2011) identified the following drivers of knowledge management in organizations: competition, customer focus, the challenge of a mobile workforce, equity in the workplace, and the global imperative. 
The basic organizational knowledge management processes adopted from the literatures are briefly described as follows:

\begin{tabular}{|l|l|l|l|}
\hline 1. & $\begin{array}{l}\text { Knowledge } \\
\text { creation } \\
\text { acquisition }\end{array}$ or & $\begin{array}{l}\text { Alavi \& Leidner, } \\
2001 ; \text { Kahreh, 2011 }\end{array}$ & $\begin{array}{l}\text { This refers to the process of } \\
\text { generating knowledge } \\
\text { internally and/or acquiring } \\
\text { it from external sources }\end{array}$ \\
\hline 2. & $\begin{array}{l}\text { Knowledge } \\
\text { storage }\end{array}$ & $\begin{array}{l}\text { Alavi \& Leidner, } \\
2001 ; \text { Kahreh, 2011 }\end{array}$ & $\begin{array}{l}\text { This refers to the process of } \\
\text { knowledge structuring and } \\
\text { storing that makes it more } \\
\text { formalized and accessible }\end{array}$ \\
\hline 3. & $\begin{array}{l}\text { Knowledge } \\
\text { retrieval, } \\
\text { transfer } \\
\text { sharing }\end{array}$ & $\begin{array}{l}\text { Alavi \& Leidner, } \\
2001 ; \text { Kahreh, 2011 }\end{array}$ & $\begin{array}{l}\text { This refers to the process of } \\
\text { transferring, disseminating } \\
\text { and distributing knowledge } \\
\text { in order to make it } \\
\text { available to those who need } \\
\text { it. }\end{array}$ \\
\hline 4. & $\begin{array}{l}\text { knowledge } \\
\text { application }\end{array}$ & $\begin{array}{l}\text { Alavi \& Leidner, } \\
2001 ; \text { Kahreh, 2011 }\end{array}$ & $\begin{array}{l}\text { The utility of Knowledge } \\
\text { management lies in its } \\
\text { application to decision- } \\
\text { making by incorporating } \\
\text { Knowledge resources into } \\
\text { the organization's products, } \\
\text { services and practices in } \\
\text { order to derive value from } \\
\text { it. }\end{array}$ \\
\hline 5. & $\begin{array}{l}\text { Knowledge } \\
\text { protection }\end{array}$ & Momeni et-al., 2011 & $\begin{array}{l}\text { Knowledge protection } \\
\text { refers to the ability to } \\
\text { protect organizational } \\
\text { knowledge from illegal } \\
\text { and/or inappropriate use or } \\
\text { theft }\end{array}$ \\
\hline
\end{tabular}


Table 2: Knowledge Management Approaches

\begin{tabular}{|l|l|}
\hline Approaches & Main focus \\
\hline Technological & $\begin{array}{l}\text { Enhancing KM quality by supplying tools for } \\
\text { effective storage and distribution of knowledge }\end{array}$ \\
\hline Intellectual asset & $\begin{array}{l}\text { Enhancing KM quality by valuing knowledge assets } \\
\text { to financial terms and reflecting them in accounting } \\
\text { practices }\end{array}$ \\
\hline $\begin{array}{l}\text { Organizational } \\
\text { learning }\end{array}$ & $\begin{array}{l}\text { Facilitating knowledge creation and sharing by } \\
\text { developing positive work environment or effective } \\
\text { reward systems }\end{array}$ \\
\hline Process & $\begin{array}{l}\text { Enhancing KM quality by identifying key processes } \\
\text { on which important knowledge flows, and managing } \\
\text { them formally. }\end{array}$ \\
\hline Philosophical & $\begin{array}{l}\text { Gaining a higher understanding of knowledge lead } \\
\text { by asking questions such as 'do we know what we } \\
\text { do not know' towards development of new ways of } \\
\text { thinking }\end{array}$ \\
\hline
\end{tabular}

Source: Kahreh, 2011

Any organization that dynamically deals with a changing environment ought not only to process information efficiently but also create information and knowledge (Herciu et-al., 2011). "Knowledge Management caters to the critical issues of organizational adaptation, survival and competence in face of increasingly discontinuous environmental change. Essentially, it embodies organizational processes that seek synergistic combination of data and information processing capacity of information technologies and the creative and innovative capacity of human beings" (Kahreh, 2011). Some of the knowledge management drivers include competition, customer focus, the challenge of mobile workforce, equity in the workplace, and the global imperative (Herciu et-al., 2011). According to Gupta et-al. (2009, cited in Momeni et-al., 2011) core competencies (CC) and knowledge management (KM) is cumulative is sustaining competitive advantage for firms. Also they noted that competences can be connected to (a) the firm's resources and property and (b) the capabilities of individuals and organizations, knowledge, processes, routines, and culture. In organizations, competencies are sets of abilities and know how accumulated over time (Gupta et-al., 2009, cited in Momeni et-al., 2011). 
Stakeholder Management, Knowledge Management \& Triple Bottom Line Linkages

Studies have explored and identified the interrelatedness between stakeholder management and knowledge management and/or knowledge management and triple bottom line (Herciu et-al., 2011). Herciu et-al. (2011) proposed a behavioural model of management resulting from synergy between knowledge management and triple bottom line. From synergy between the two dimensions, triple bottom line and knowledge management, results: eco-knowledge, socioknowledge, and ecological-knowledge in order to increase firm competitiveness and sustainability.

Our approach categories corporate stakeholders as follows: economic stakeholders, social stakeholders and environmental stakeholders, and knowledge acquired from these stakeholder groups are categorized as: economic knowledge, social knowledge and environmental knowledge.

The knowledge management procedure combines these two categorization in order to provide $21^{\text {st }}$ century managers with efficient and effective tools for corporate performance management. The resulting management approaches are: Economic stakeholder management, Environmental stakeholder management and Social stakeholder management. 
Economic Stakeholder

Management
Environmental

Stakeholder Management

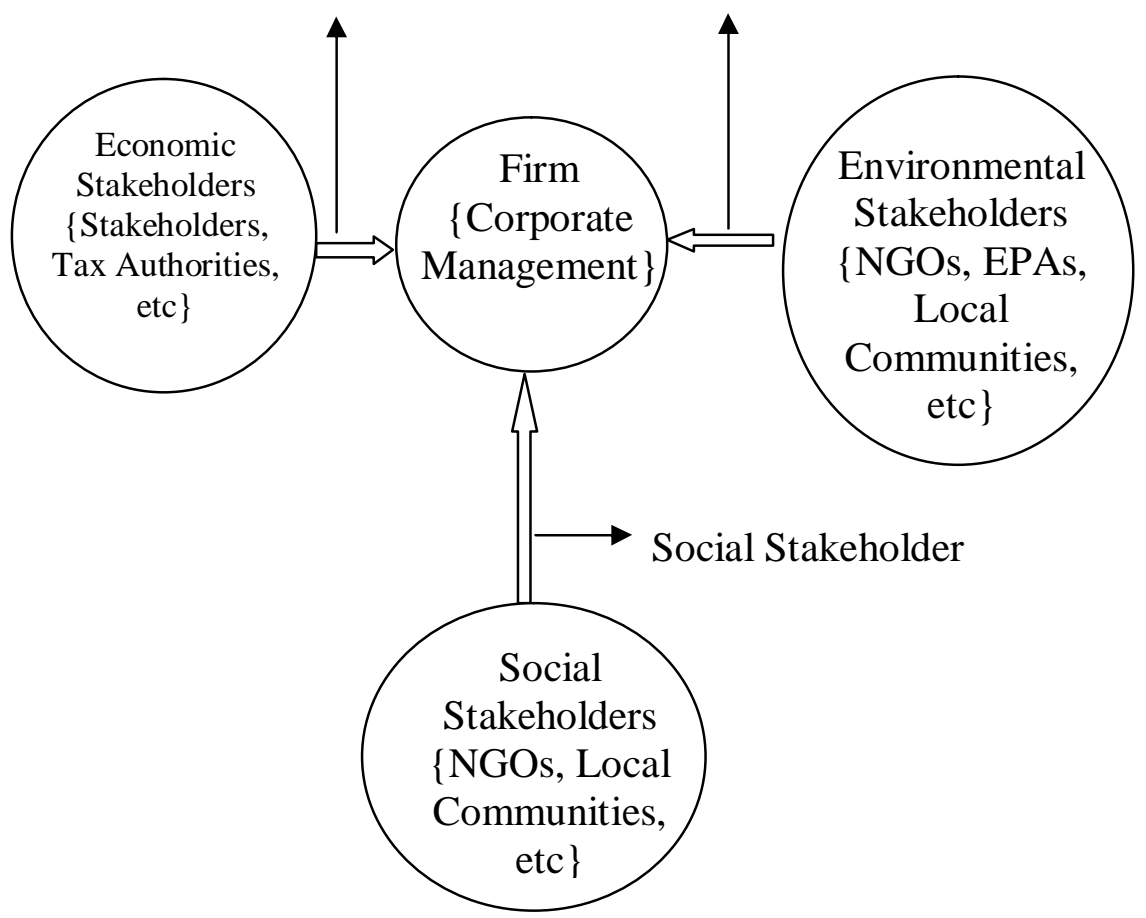

\section{Research Design and Methodology}

An exploratory study was carried out to ascertain the perception of corporate managers, accounting and finance academics. Using the snow-ball sampling technique, the sample size was estimated at 56. The questions were based on a structured five point Likert scale with the following options: Strongly Agree (SA); Agree (A); Indifferent (ID); Disagree (D); Strongly Disagree (SD) with the associated weights of 5, 4, 3, 2 and 1 respectively. Three hypotheses were formulated and analyzed using two-sample Kolmogorov-Smirnov Test. 
Table 3: Descriptive Statistics of Questionnaire Responses

\begin{tabular}{|c|c|c|c|c|c|c|c|c|}
\hline $\begin{array}{l}\text { Item } \\
\text { no }\end{array}$ & $\begin{array}{l}\text { Question } \\
\text { description }\end{array}$ & $\mathbf{S A}$ & $\mathbf{A}$ & ID & D & SD & Mean & $\begin{array}{l}\text { Standard } \\
\text { deviation }\end{array}$ \\
\hline 1. & $\begin{array}{l}\text { Stakeholder } \\
\text { knowledge is a key } \\
\text { organizational } \\
\text { resource }\end{array}$ & 36 & 4 & 5 & 7 & 4 & 4.0893 & 1.37876 \\
\hline 2. & $\begin{array}{lr}\text { Stakeholder } & \\
\text { knowledge } & \text { is } \\
\text { necessary } & \text { for } \\
\text { aligning } & \text { corporate } \\
\text { strategy } & \text { with } \\
\text { stakeholder interest }\end{array}$ & 29 & 9 & 2 & 10 & 6 & 3.8036 & 1.49447 \\
\hline 3. & $\begin{array}{lr}\text { Employees are } & \text { key } \\
\text { consideration } & \text { in } \\
\text { establishing } & \\
\text { knowledge } & \\
\text { acquisition } & \text { and } \\
\text { management process }\end{array}$ & 30 & 13 & 3 & 4 & 6 & 4.0179 & 1.36836 \\
\hline 4. & $\begin{array}{l}\text { To facilitate } \\
\text { knowledge } \\
\text { processing and flow } \\
\text { in organization } \\
\text { management needs to } \\
\text { establish a } \\
\text { knowledge } \\
\text { management system }\end{array}$ & 33 & 8 & 8 & 5 & 2 & 4.1607 & 1.18746 \\
\hline 5. & $\begin{array}{l}\text { Integrating } \\
\text { knowledge } \\
\text { management systems } \\
\text { into management } \\
\text { information system } \\
\text { renders effective and } \\
\text { efficient management } \\
\text { decision making }\end{array}$ & 39 & 9 & 4 & 3 & 1 & 4.4643 & 97168 \\
\hline 6. & $\begin{array}{l}\text { Environmental } \\
\text { knowledge from } \\
\text { stakeholders about } \\
\text { environmental claims } \\
\text { and issues promote }\end{array}$ & 34 & 4 & 5 & 8 & 5 & 3.9643 & 1.42182 \\
\hline
\end{tabular}




\begin{tabular}{|c|c|c|c|c|c|c|c|c|}
\hline & $\begin{array}{l}\text { corporate } \\
\text { environmental } \\
\text { performance } \\
\end{array}$ & & & & & & & \\
\hline 7. & $\begin{array}{lr}\text { Stakeholders } & \text { react } \\
\text { negatively } & \text { when } \\
\text { environmental } & \text { issues } \\
\text { are neglected } & \end{array}$ & 24 & 10 & 5 & 10 & 7 & 3.6071 & 1.49762 \\
\hline 8 . & $\begin{array}{l}\text { Social knowledge } \\
\text { from stakeholders } \\
\text { about social claims } \\
\text { and issues promote } \\
\text { social performance }\end{array}$ & 27 & 13 & 5 & 4 & 7 & 3.8750 & 1,41502 \\
\hline 9. & $\begin{array}{lr}\text { Stakeholders react } \\
\text { negatively } & \text { when } \\
\text { social issues are } \\
\text { neglected }\end{array}$ & 27 & 9 & 10 & 5 & 5 & 3.8571 & 1.35417 \\
\hline 10. & $\begin{array}{l}\text { Sustainable } \\
\text { corporate } \\
\text { performance requires } \\
\text { the identification and } \\
\text { integration of firm } \\
\text { specific stakeholder }\end{array}$ & 35 & 11 & 4 & 5 & 1 & 4.3214 & 1.06356 \\
\hline 11. & $\begin{array}{l}\text { Knowledge } \\
\text { management systems } \\
\text { provide management } \\
\text { with knowledge } \\
\text { processing power } \\
\text { capable of creating } \\
\text { value for each } \\
\text { stakeholder group }\end{array}$ & 34 & 6 & 5 & 7 & 4 & 4.0536 & 1.36741 \\
\hline 12. & $\begin{array}{l}\text { Knowledge } \\
\text { management systems } \\
\text { provide management } \\
\text { with knowledge } \\
\text { useful for stakeholder } \\
\text { conflict-management }\end{array}$ & 29 & 9 & 2 & 10 & 6 & 3.8036 & 1.49447 \\
\hline 13. & $\begin{array}{l}\text { To ensure successful } \\
\text { KMS implementation } \\
\text { a rost/benefit } \\
\text { analysis needs to be }\end{array}$ & 30 & 13 & 3 & 4 & 6 & 4.0179 & 1.36836 \\
\hline
\end{tabular}




\begin{tabular}{|l|l|l|l|l|l|l|l|l|}
\hline & carried out & & & & & & & \\
\hline 14. & $\begin{array}{l}\text { Balancing the interest } \\
\text { of various } \\
\text { stakeholder groups } \\
\text { would ultimately } \\
\text { meet triple bottom } \\
\text { line performance }\end{array}$ & 33 & 8 & 8 & 5 & 2 & 4.1607 & 1.18746 \\
\hline 15. & $\begin{array}{l}\text { Knowledge resources } \\
\text { provide tools for } \\
\text { management strategic } \\
\text { decision-making }\end{array}$ & 26 & 16 & 5 & 6 & 3 & 4.0000 & 1.22103 \\
\hline
\end{tabular}

Source: Field Survey (2012)

\section{Hypothesis formulation:}

H1: The synergistic effect derived from the interface of the three performance areas would not provide management with strategies for survival and growth in the long-run.

H2: Knowledge Management Systems is not related to the development of Core Competencies in sustainable organizations by providing managers with knowledge capable of influencing environmental, social and economic reaction and adaptation.

H3: Corporate triple-bottom-line performance of organization is not strengthened by a sustainable stakeholder categorization for firms which provide managers with a system for assessing stakeholder needs.

Consider analysis Result for Hypothesis 1, 2 and Hypothesis 3:

Table 4: Frequency Distribution of Respondents

\begin{tabular}{|l|l|}
\hline Group & N \\
\hline Academics & 35 \\
Corporate Managers & 21 \\
Total & $\mathbf{5 6}$ \\
& \\
\hline
\end{tabular}




\section{Hypothesis one:}

\section{Test Statistics}

\begin{tabular}{|l|l|l|}
\hline & H1 & \\
\cline { 1 - 2 } Most Extreme & & \\
Differences & & 381 \\
& Absolute & .029 \\
& Positive & -.381 \\
Kolmogorov-Smirnov Z & Negative & 1.380 \\
Asymp. sig. (2-tailed) & & .044 \\
& & \\
\hline
\end{tabular}

a. Grouping Variable: Group

\section{Decision Rule:}

Using the $K-S$ table, which tests the acceptability of the model from a statistical perspective, the decision rule is as follows: $D_{\text {calculated }}>D_{\text {table }}$ value - Reject the null hypothesis; and if, $D_{\text {table value }}>D_{\text {calculated }}-A c c e p t$ the null hypothesis.

Decision: Since, D calculated $>D_{\text {table value }}: 1.380>0.182$ (at 0.05 critical value). Reject the null hypothesis and accept the alternate. Thus, the synergistic effect derived from the interface of the three performance areas would provide management with strategies for survival and growth in the long-run.

Hypothesis Two and Three:

\section{Test Statistics}

\begin{tabular}{|l|l|l|}
\hline & $\mathrm{H} 2$ & $\mathrm{H} 3$ \\
\hline Most Extreme Differences & & \\
Absolute & .229 & .171 \\
Positive & .086 & .000 \\
& -.229 & -.171 \\
Negative & .828 & .621 \\
Kolmogorov-Smirnov Z & .499 & .835 \\
Asymp. sig. (2-tailed) & & \\
\hline
\end{tabular}

a. Grouping Variable: Group 


\section{Decision:}

H2: Since, D calculated $>$ D table value: $.828>0.182$ (at 0.05 critical value). Reject the null hypothesis and accept the alternate. Thus, Knowledge Management Systems is related to the development of Core Competencies in sustainable organizations by providing managers with knowledge capable of influencing environmental, social and economic reaction and adaptation.

H3: Since, D calculated > D table value: .621>0.182 (at 0.05 critical value). Reject the null hypothesis and accept the alternate. Thus, corporate triple-bottom-line performance of organizations is strengthened by a sustainable stakeholder categorization for firms which provide managers with a system for assessing corporate stakeholder needs.

\section{Conclusion and Recommendation}

We have to agree that in the current context of (1) increasing interconnectedness between economic actors, social actors and ecological actors, (2) consistent critical externalities for all types of firms confronted with an increasing competition in the local and/or international market, (3) tremendous impact of the new information and communication technology on each firm, in terms of strategic development and of organizational behavior, strategic management relies increasingly on the intangible assets in achieving corporate or market goals' (Herciu et-al., 2011). Considering knowledge as an intangible asset highlights the need for adequate KMS infrastructure in organizations to ensure the realization of its potential benefit. The following steps could be adopted in institutionalizing the proposed KMS model in organizations: (1) define clear organizational objectives; (2) Define clear strategies for achieving the objectives; (3) Establish knowledge management system (KMS) considering organizational infrastructure such as facilities for knowledge creation/acquisition, storage and retrieval, transfer, sharing and application; (4) Integrate the knowledge management system (KMS) infrastructure into the corporate management information system; (5) Align the knowledge management system (KMS) with organizational functional units; (6) Recognize the role of human resource management (HRM) in the knowledge management (KM) development process. 
One major challenge faced by organizations in adopting and implementing KMS is knowledge. Therefore due consideration of organizational infrastructure and organization's need for knowledge is necessary. Where possible a knowledge database system needs to be established so historical knowledge can be gathered to aid future management decisions.

\section{Suggestions for further Research}

The proposed KMS model could be improved by identifying other factors (such as: rapid globalization, developments I ICT, cross-border reporting requirements, capital market liberalization, etc) affecting knowledge acquisition an dissemination in modern organizations could also be investigated. The proposed model could be redefined by extending its application to other sectors in the economy any systems for multinational companies.

\section{References}

Alavi, M., and Leidner, D.E. (2001). Review: Knowledge management and knowledge management systems: Conceptual foundations and research issue. MIS quarterly, 25(1), 107-136. The Society for information Management and The Management Information Systems Research center of the University of Minnesota, and The Association for Information Systems, Retrieved from http://www/jstor.org/stable/3250961.

Allen, T.J. (1977). Managing the Flow of Technology. Cambridge, MA: MIT Press.

Alrawi, K., and Alrawi, W. (2011). Managers' perception of potential impact of knowledge management in the workplace: Case study. AMERICAN JOURNAL OF SOCIAL AND MANAGEMENT SCIENCES, 2 (1) 188-195. doi: 10.5251/ajsms.2011.2.1.188.195.

Cronin, B. (2001). Knowledge management, Organizational culture and Anglo-American higher education. Journal of Information Science, 27(3), 129-137. Doi:10.1177/016555150102700302. 
Ezzati Jivan, M., and Zarandi, M. (2012). Factors Effective on Knowledge Management in Service-Oriented Organizations (Senior Managers Opinion Using Analytical Hierarchy Process (AHP). International Journal of Business and Management, 7(5). Doi:10.5539/ijbm.v7n5p150.

Gold, A.H., Malhotra, A., and Segars, A.H. (2001). Knowledge Management: An Organizational Capabilities Perspective. Journal of Management Information Systems, 2(1), 185-214. Retrieved from http://web.ebscohost.com/ehost/pdfviewer.pdfviewer?sid=7c60 ef26-82ea-4861-81094382a16d4f0a@sessionmgr113\&vid=2\&hid=119.

Greenberg, S., and Roseman, M. (2003). Using a Room Metaphor to Ease Transitions in Groupware. In M.S. Ackerman, V. Pipek, \& V. Wulf (Eds.), Sharing expertise: beyond knowledge management (pp.203-256). Cambridge, MA: The MIT Press.

Grudin, J. (1988). Why CSCW Applications Fail: Problems in the design and Evaluation of Organizational Interfaces. Proceedings of the Conference on Computer-Supported Cooperative Work, 85-93.

Herciu, M., Ogrean, C., and Belascu, L. (2011). A Behavioural Model of Management - Synergy between triple Bottom Line and Knowledge Management. World Journal of Social Sciences, 1 (3), 172-180.

Kaplan, R.S. and Norton, D.P. (1992). The balanced scorecardmeasures that drive performance. Harvard Business Review, Vol. 70, No. 1, pp. 71-79.

Kaplan, R.S. and Norton, D.P. (1996a). Linking the balanced scorecard to strategy. California Management Review, Vol. 39, No. 1, pp. 53-79. 
Kaplan, R.S. and Norton, D.P. (1996b). The Balance Scorecard, Boston, MA: Harvard Business School Press.

Kaplan, R.S. and Norton, D.P. (1996c). Using the balanced scorecard as a strategic management system. Harvard Business Review, Vol. 74, No. 1, pp. 75-85.

Kaplan, R.S. and Norton, D.P. (2001). Transforming the balanced scorecard from performance measurement to strategic management: Part 1, Account Horizons, Vol. 15, No.1, pp.87104.

Kaplan, R.S. (2001). Strategic performance measurement and management in nonprofit organizations. Non profit Management and Leadership, Vol. 11, No.3, pp.353-370.

Karmzadegan, D., Tanha, J., and Majd, E. (2011). Providing a comprehensive knowledge management Model. Journal of Research in International Business and Management, Vol. 1(6)pp. 155-163.

Kuah, T.C., and Wong, Y.K. (2011). Knowledge management performance measurement: A Review. African Journal of Business Management, Vol. 5(15), pp.6021-6027.

Mahdi, R.O., Almsafir, K.M., and Yao, L. (2011). The role of knowledge and knowledge management in sustaining competitive advantage within organization: A review. African Journal of Business Management. Vol. 5(23), pp. 9912-9931.

Mishra, B. (2011). Knowledge Management process in two Learning Organizations. Journals of Knowledge Management, Vol. 15, No. 2.

Monnavrian, A. and Amini, A. 92009). Do interactions within networks lead to knowledge Management. Business Strategy Series, Vol. 10, No.3, pp. 139-155. 
Momeni, M., Shaabani, e., Ghasemi, R. and Abdullahi, B. (2011). Canonical Correlation Analysis between Knowledge Management and Core Competencies: A case Study in the Iranian Automotive Industry. American Journal of Scientific Research, Vol. 25, pp. 70-81.

Nonaka, I. (1991). The knowledge-creating company. Harvard Business Review, Vol. 69, Nov.-Dec., pp. 96-104.

Nonaka, I. and Takeuchi, H. (1995). The knowledge-Creating Company, Oxford University Press, New York.

Nonaka, I., Von Krogh, G., and Voelpel, S. (2006). Organizational Knowledge Creation Theory: Evolutionary paths and future advances. Organization Studies, Vol. 27, No. 8, pp. 1179-1208.

Osisioma, B.C. (2010). Global Financial Crisis: Impact on the changing Face of Accountancy profession. Frontier Lecture Series 001. Department of Accountancy, Nnamdi Azikiwe University, Awka.

Penuel, B., and Cohen, A. (2003). Coming to the Crossroads of Knowledge, Learning, and technology: Integrating Knowledge Management and workplace Learning. I M.S. Ackerman, V. Pipek, \& V. Wulf (Eds.), Sharing expertise: beyond knowledge management (pp. 57-76). Cambridge, MA: The MIT Press.

Perez-soltero, A., Barcelo-valenzuela, M., Sanchez-schmitz, G., Rodriguez-elias, O.M. (2009). A Computer prototype to Support Knoeledge Audits in Organizations. Knowledge and Process Management, 16(3), 124-133. Doi:10.1002/kpm.

Revilla, E., Prieto I.M. and Prado, B.R. (2010). Knowledge Startegy: Its Relationship to Environmental Dynamism and Complexity in Product Development. Knowledge and process Management, 17(1), 36-47, doi:10.1002/kpm.

Shahbudin, A.S. Nejati, M., and Amran, A. (2011). Sustainability based knowledge management performance evaluation system 
(SKMPES): Linking the higher learning insituties with the bottom billions. African Journal of Business Management, Vol. 5 (22), pp. 9530-9540.

Snowden, D. (2005). Complex Acts of Knowing: Paradox and descriptive Self-Awareness. Bulletin of the American Society for information Science and technology, 29(4), 23-28. Doi:10.1002/bult.284.

Starbuck, W.H. (1992). Learning by knowledge-Intensive firms. Journal of Management Studies, 29(6), 713-740. Retrieved from

http://books.google.de/books?hl=de\&lr=\&id=aasr4HOjDmIC\& oi=fnd\&pg=PA181\&dq=learning + by + knowledge+intensive+fir

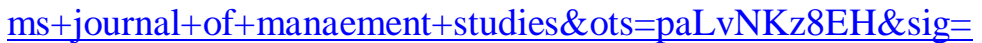
HXfpRwrZv3SUFIjFvWgPppaEFI\# $\mathrm{v}=$ onepage $\& \mathrm{q}=\& \mathrm{q}=\& \mathrm{f}=$ false.

UDUDEC, C.N., and MAZILESCU, V. (2011). Knowledge Management System and User Modeling. Economics and Applied Informatics, (1), 41-48.

Von Krogh, G. (1998). Care in Knowledge Creation. California Management Review, 40(3), 133-153. Retrieved from http://www.alexandria.unisg.ch/publications/by-year/Y1998/30617/L-en. 